\title{
Unresolved and Unresolvable? Tensions in the Refugee Regime Megan Bradley*
}

he two cardinal norms of the refugee regime are the right to seek asylum and non-refoulement - that is, the right of refugees not to be returned to ( a country where their lives or freedom would be threatened. In recent decades, however-particularly in the Global North-many politicians and segments of the public have come to view national interests as antithetical to these norms, leading to the erection of ever more elaborate barriers to deter unwanted arrivals. Despite these efforts, the number of refugees and displaced persons worldwide continues to grow, reaching 68.5 million in 2018 , the highest levels since World War II. ${ }^{1}$ The problem is not just that more and more refugees are forced from their homes but also that fewer and fewer are able to access so-called "durable solutions" to displacement, whether voluntary return to their countries of origin, local integration in host states, or resettlement elsewhere. Instead, millions are locked in limbo, with the average refugee situation now dragging on for over twenty-five years. ${ }^{2}$

This situation has prompted a flurry of efforts to repair the foundering refugee regime, from the negotiation of a new Global Compact on Refugees to a variety of proposals from experts of various stripes. ${ }^{3}$ Many of these efforts attempt, implicitly or explicitly, to resolve tensions between legal principles, moral duties, and national interests related to refugees, for example, by stressing refugees' positive economic contributions to their host societies. Notwithstanding the clear need to rethink and revive the refugee regime, this essay questions the drive toward oversimplification that has characterized many debates on reforming responses to refugees. It recognizes that some of the aforementioned tensions are "baked

${ }^{\star}$ This research was supported by the Social Sciences and Humanities Research Council of Canada.

Ethics \& International Affairs, 33, no. 1 (2019), pp. 45-56.

(c) 2019 Carnegie Council for Ethics in International Affairs

doi:10.1017/So892679418000874 
into" the problem of refugeehood, given that the state system exists, at least in part, to draw lines between insiders and outsiders. In this system, the capacity to make effective rights claims is tied to recognition as a legitimate member of the political community of the state-a recognition refugees lack, and have limited power to contest. ${ }^{4}$

Debates on the interplay of law, morality, and national interest related to the refugee regime have typically focused on the obligation to admit refugees, and on "responsibility sharing" through Northern support for states in the Global South, which collectively host more than 85 percent of the world's refugees. ${ }^{5}$ I seek to advance the conversation by exploring how legal norms, moral values, and national interests are also entangled in efforts to support durable solutions for refugees, focusing on voluntary repatriation. What does recognition of the intrinsic, and in some senses irreconcilable tensions between law, morality, and national interests mean for efforts to support "solutions" for refugees? Do these tensions render the very notion of solutions chimerical? Acknowledging these fundamental tensions is not to be defeatist about the possibility of strengthening responses to refugees. I argue that advancing durable solutions, however imperfect, does not mean definitively overcoming the tensions that characterize the refugee predicament writ large, but rather that it requires an ongoing process of navigating these tensions to identify and promote context-specific opportunities to reposition refugees as full and equal citizens as a critical step toward reducing (if not eliminating) their precarity.

\section{What Is at Stake?}

At first glance, it may appear that in the contemporary refugee regime there has been a decisive tipping of the scales in favor of national interests at the expense of legal norms and moral values, such as equity, compassion, and justice. However, upon closer examination the picture is, unsurprisingly, more complicated.

\section{Legal Norms}

Under international law, states have a modest suite of specific obligations toward refugees, encapsulated primarily in the 1951 Convention Relating to the Status of Refugees and its 1967 Protocol. These obligations are limited by the remarkably narrow definition of "refugee" established in these two documents. The Convention indicates that a refugee is an individual who, "owing to a wellfounded fear of being persecuted for reasons of race, religion, nationality, 
membership of a particular social group or political opinion, is outside the country of his nationality and is unable or, owing to such fear, is unwilling to avail himself of the protection of that country." "Many who would be considered refugees according to vernacular or common moral understandings of the termsuch as those who have fled war but have not suffered direct persecution-do not qualify for protection under this definition. ${ }^{7}$ International refugee law is predicated on the right to seek asylum, but this is not matched by a corresponding legal right to be granted asylum. The acceptance of refugees is thus fundamentally shaped by political considerations and, to a lesser extent, related moral commitments.

The prohibition on refoulement is the second cardinal legal rule of the refugee regime, and as a principle of customary international law it is binding even on those states that have not signed the refugee convention. Legally, states cannot simply turn refugees away. However, states exercise remarkable and relentless creativity in curtailing access to their territories through the implementation of non-entrée and neo-refoulement measures. Even when refugees enjoy protection from refoulement, this is not a durable solution for their marginalization from the political community of the state. ${ }^{8}$

\section{Moral Values}

Existing legal principles on refugee protection naturally reflect the interests and concerns of the states that negotiated and interpret them. For the Western states that drove the original development of the regime's legal architecture, the refugee issue had intertwined moral and geopolitical salience. For example, protecting those fleeing communism and conflicts in the Soviet Union's "sphere of influence" provided a concrete opportunity to demonstrate the moral superiority of liberal democracy. Even still, Western states were determined to limit their obligations. They therefore articulated a relatively spare set of core legal commitments to refugees, leaving the broader dimensions of responses to refugees to be framed in moral and political terms. Thus, states typically portray their response to refugee situations as a humanitarian undertaking, an expression of charity or generosity, rather than as a responsibility or an act of justice. Political theorists and activists of many different perspectives vociferously challenge this perspective, arguing that states-particularly wealthy, liberal democracies - are obliged to admit and assist refugees on the basis of, among other things, liberal or cosmopolitan conceptualizations of justice. ${ }^{9}$ 
While it is impossible to explore these debates in full here, it is noteworthy that a tendency has emerged among some advocates and scholars to discuss the issue in an echo chamber of shared "progressive" opinions, and to dismiss any opposition as inherently racist or xenophobic, or as a parochial reflection of illegitimate national interests. ${ }^{10}$ From this perspective, the idea of tensions between legal norms, moral values, and national interests is largely moot because controlling entry to and membership in a state are cast as obviously immoral. This move marks a refusal to grapple with some of the more nuanced defenses of a state's right to decide who belongs, offered by scholars such as Michael Walzer (on communitarian grounds) and David Miller (on the basis of liberal nationalism). These defenses jibe with the sincerely held-if highly contestable-values of many citizens in states confronting refugee flows. ${ }^{11}$ Roughly put, these perspectives share the idea that nations may constitute distinctive and valuable communities. Thus, to the extent that accepting large numbers of refugees would negatively change or corrode the identities of these groups, and the state's capacity to protect its citizens' rights and to serve their needs, states may have a legitimate interest in restricting the number of refugees they accept. This meshes with Nigel Biggar's observation in his contribution to this roundtable that a government may be understood to have a moral responsibility to promote the legitimate interests of its people, albeit within the bounds of international justice. ${ }^{12}$ The proliferation of abuses against refugees that are unconscionable by most moral codes, including the perspectives advanced by scholars such as Walzer and Miller, obscures these more complex disagreements over national interests and moral values relating to refugees.

\section{National Interests}

State interests vis-à-vis refugees are enmeshed with moral values, and are also highly variable, depending in part on historical experience, geostrategic considerations, and whether the state creates or hosts refugees, or both. Broadly speaking, the interests of host and donor states in the contemporary refugee regime reflect different blends of five interconnected motivations. ${ }^{13}$

First, states generally seek to limit the number of refugees within their borders, in particular with states in the Global North dedicated to keeping most refugees contained in the Global South. Intertwined with this perceived interest is a moral claim fundamental to the state system: that sovereign states legitimately have the prerogative-with only modest limits - to regulate entry to and membership in the national political community. 
Second, states strive to limit the costs-financial, political, and in terms of perceived security risks-of refugee situations. For host states this often entails supporting more financially expensive responses, such as creating camps and withholding work permits (leaving refugees reliant on aid distributions), in order to limit the perceived political costs of taking in refugees. These political costs include the widely held perceptions that refugees not only overburden social welfare systems and "steal" jobs from citizens but also that they may be criminals or terrorists. Southern host states also try to leverage financial and political concessions from donor states in exchange for accommodating refugees.

In many cases states and politicians not only try to limit the political cost of letting refugees in, they also look to maximize the domestic political gains that may be reaped from vilifying refugees. For some leaders these gains appear so significant that they abrogate ostensibly deeply-held values. For example, Australia, a self-proclaimed human rights flag-bearer, embraces policies flagrantly incompatible with human rights, such as indefinitely detaining asylum seekers, in order to pander to voters opposed to the arrival of refugees. For many donor and host states, limiting the overall cost of refugee situations hinges on limiting their duration and precluding the possibility of refugees staying permanently. As I discuss below, this creates an incentive for states to push to end refugee situations as quickly as possible, ideally through what they view as the preferred solution of voluntary repatriation.

A third motivation, particularly for donor states, is that supporting the refugee regime creates a "release valve" that limits a conflict's destructive toll, at least in terms of loss of life, thereby lessening pressure for even more costly and riskier forms of intervention, such as military engagement. Thus, in conflicts such as occurred in Bosnia and Herzegovina in the 1990s, humanitarian support for refugees has served as a cover for Western inaction to stop the violence that was driving the exodus.

Fourth, as Gareth Evans argues in his introduction to this roundtable, countries have an "interest in being, and in being seen to be, a good international citizen." 14 Some countries, such as Canada under the governments of Pierre Elliot Trudeau and Justin Trudeau, have used the refugee regime to cultivate or rehabilitate a virtuous international reputation and to assert a particular interpretation of national identity as compassionate, supportive of diversity, and distinct from other, less generous neighbor countries.

Fifth, states share a broad interest in avoiding heightened accountability toward refugees-both for the abuses that force them from their homes and for violations 
of their rights while displaced. Demands for accountability for rights violations have been a prominent feature of post-Cold War politics, but refugees have often been sidelined in such struggles. While refugees have certainly contested this exclusion, including by documenting and protesting violations against them and bringing forward legal claims, typically neither the states that create refugees nor those that abuse their rights are held to account for these acts.

\section{Reconciling Tensions, Irreconcilable Tensions}

Many recent efforts to revamp the refugee regime and reform states' restrictive policies toward refugees have attempted to reconcile the tensions between these legal principles, moral commitments, and national interests. Some, for example, have appealed to states' interests by celebrating the displaced as assets who can make positive economic, social, creative, and intellectual contributions to their host societies-echoing an earlier UNHCR campaign recalling that "Einstein was a refugee." Others have proposed the creation of new transnational communities in which the displaced can flourish economically and socially. ${ }^{15}$

While assessing the plausibility and potential efficacy of all such proposals is not possible here, I wish to make a few observations on the veritable cottage industry that has emerged around recommendations for reforming the refugee regime. These proposals posit that refugee crises need not be intractable by highlighting opportunities to use persuasion, effective bargaining, and the realignment of interests to reconcile extrinsic tensions between legal norms, moral values, and perceived national interests. Perhaps unsurprisingly, they remain largely silent on the intrinsic tensions between the state system itself and efforts to uphold refugees' rights. ${ }^{16}$ But as David Turton observes, the refugee regime "is the nation-states' response to the refugee problem, from which it follows that the prime purpose of the regime is not to protect refugees but to protect the international system of nation-states by 'normalizing' the figure of the refugee." ${ }^{17}$ In her seminal discussion of refugeehood in The Origins of Totalitarianism, Hannah Arendt relatedly argues that refugee outflows expose the poverty of human rights claims and the lie in justifying state power on the grounds that states protect human rights. For rights claims to be truly effective, Arendt suggests, they must be made by individuals recognized as legitimate members of the state-a status arbitrated by states themselves. As "stateless, rightless scum of the earth," the displaced have been cast out of the state and thus lack "the right to have rights," and even 
the power to meaningfully contest their relegation. ${ }^{18}$ Contrary to Arendt's expectations, refugees have indeed contested their marginalization and have, in some cases, made their claims heard. ${ }^{19}$ Still, the force of her critique continues to resonate: even as refugees and their advocates challenge their marginalization and perhaps make modest gains, the logic of the state system remains one in which the expulsion of refugees by states with virtual impunity remains an ever-present risk. Indeed in some accounts, the creation of refugees is not only a risk in the state system but integral to its very operation. ${ }^{20}$

\section{Durable Solutions and Gradual Progress}

Where does the intrinsic tension between the notion of refugees as rights-holders and the nature of the state system itself leave efforts to reform the system, and the possibility of meaningful solutions to displacement? ${ }^{21}$ This question is particularly pertinent when we expand the conversation beyond the typical focus on asylumseeking and non-refoulement to consider tensions associated with durable solutions to displacement, particularly voluntary repatriation.

While the term "durable solution" does not appear in key legal standards, such as the 1951 Refugee Convention, the UNHCR Statute does mandate the agency to seek "permanent solutions for the problem of refugees by assisting Governments ... to facilitate the voluntary repatriation of such refugees, or their assimilation within new national communities." ${ }^{22}$ Durable solutions are often defined simply in terms of the three routes for ending displacementlocal integration, resettlement, and voluntary repatriation-instead of in terms of sustainable outcomes. However, a refugee who, for example, returns to her home country only to be displaced anew has clearly not benefited from a solution to her predicament in any meaningful sense. Indeed, although enabling durable solutions is in theory the ultimate goal of refugee protection, there is considerable murkiness surrounding what counts as a durable solution and what these purported solutions aim to achieve. That said, by any definition the search for durable solutions for refugees is failing. Over recent decades, less than 1 percent of refugees worldwide have been resettled each year, and estimates on local integration (refugees formally acquiring citizenship in their host countries) in the Global South are even lower. In 2016, some 552,200 refugees voluntarily repatriatedthe highest return rate since 2008, and more than double the number in 2015 , but still representing less than 2.5 percent of refugees globally. ${ }^{23}$ 
Theoretically, durable solutions are to benefit refugees, but states (and other actors) have sharp and sometimes incompatible interests in the process, reflecting the five broad elements of state interest in the refugee regime articulated above. As manifested in the context of efforts to secure durable solutions to displacement, these interests range from closing camps and freeing-up scarce humanitarian funds to preventing the return of unwanted minorities. In some cases, "solutions" advance the interests of discontented host states and overtaxed humanitarian agencies, but may, from the perspectives of refugees, create more problems than they resolve. This reality raises a critical question: Is the enjoyment of full, equal, and effective citizenship rights the gold standard or the sine qua non for durable solutions for refugees? Some argue that true solutions require the full restoration of citizenship rights or, for those who never had full citizenship rights, the recognition of the refugee as a full and equal citizen, whether in her host country, in a resettlement state, or in her state of origin. ${ }^{24}$ This position is in line with a principled focus on human rights protection, although it arguably cannot overcome Arendt's fundamental critique of these very principles, and the state system itself. Additionally, we must ask whether it is a coherent proposition when refugees pursue durable solutions in states still experiencing or emerging from conflict, in which citizenship rarely translates into reliable, robust human rights protection, regardless of whether one has been displaced. This concern is especially pressing when it comes to the "preferred" solution of voluntary repatriation, given that refugees are usually returning to countries where development prospects are bleak, mechanisms to protect their rights are fragile at best, and former neighbors and officials may be overtly and even violently opposed to their return.

\section{The Right of Return}

Despite currently low return rates, voluntary repatriation is often referred to by states and the UNHCR as the "preferred" solution to displacement. In part, this designation reflects the highly limited nature of the international legal framework around durable solutions, which is itself a reflection of states' collective interest in retaining sovereign control over entry and membership. States have no legal obligation to resettle refugees or extend citizenship to those who wish to integrate permanently into their host societies. Indeed, repatriation is the only "solution" to which refugees have a clear legal right. This is based not on the 1951 Convention, but on the broader human rights principle of the right of return, articulated in standards such as the Universal Declaration of Human Rights 
and the International Covenant on Civil and Political Rights. The problem of course is that many refugees do not want to return, and may not be able to do so without risking their lives. If conditions in a refugee's country of origin change such that return may be possible, a wide array of UN resolutions, peace treaties, and other standards stress that it should be voluntary, and take place in conditions of "safety and dignity." 25

Beyond being a legal right, repatriation is often portrayed as the preferred solution because it meshes with the sedentary and exclusionary bias of the state system, in which certain people are seen to belong in certain places. From this perspective, repatriation puts refugees back where they belong, squaring the circle of "the refugee problem" by reaffirming the logic of the state system: state power is legitimate because the state protects its citizens-including exiles who return to the fold. Arendt was skeptical, to say the least, both of this logic and of the possibility that states would ever allow refugee repatriation on a large scale. History has disproved some of her arguments on the latter count, as more than twenty-five million refugees have returned over the past twenty years (notwithstanding currently low return rates). With the notable exception of countries such as Myanmar, Bhutan, and Israel, most refugee-creating states do not directly oppose repatriation. Rather, the challenge is whether the security of returnees can be ensured and their citizenship claims made meaningful in places where citizenship has been an "axis of subordination" rather than empowerment. ${ }^{26}$

Host states have often cloaked their own interests in return by insisting that it is, in fact, also the preference of most refugees. While this claim is often disingenuous, careful ethnographic research with different refugee populations also makes clear that many refugees around the world do hope to return-in particular circumstances-to their lost homes and countries. ${ }^{27}$ In return movements from $\mathrm{El}$ Salvador to post-apartheid South Africa, some refugees have actively engaged in struggles to reform their states and make their citizenship claims meaningful. Such preferences and decisions do not defuse the intrinsic, irreconcilable tensions between law, morality, and national interests that stymie efforts to create a world without refugees. They do, however, point to the value of understanding the pursuit of durable solutions to displacement as an ongoing process. In this process, refugees' precarity, and the risk of future refugee flows, are never fully resolved -in this sense Arendt's critique holds true-but may be mitigated and managed, often through refugees' own mobilization efforts and political strategies. Listening to refugees' perspectives and trying to understand the ways in which they struggle 
toward solutions are not a panacea for the tensions that hamstring the refugee regime. But refugees themselves often have insight into progressive steps that may be taken toward improving their situations and even recasting their fractured citizenships. This suggests that recognition of the persistent and fundamentally irreconcilable tensions between law, morality, and state interests in the refugee regime does not mean that progress-inevitably modest and contingent-toward durable solutions is unattainable.

\section{Conclusion}

Optimism about durable solutions for refugees, and about a strengthened refugee regime more broadly, may seem incompatible with recognition that the creation of refugees is integral to the state system itself, reflecting unreconciled and in some senses irreconcilable tensions between law, morality, and state interests. As long as states retain largely unfettered power to determine who can be present within their borders and who is accorded membership, refugee flows will persist, showing all too clearly the costs of this system. But the scarcity-or impossibility-of solutions to the refugee problem writ large within the confines of the state system does not rule out improvements to the regime, including gradual, tentative progress toward durable solutions for displaced individuals and communities.

\section{NOTES}

${ }^{1}$ UNHCR, "Global Trends 2017" (Geneva: UNHCR, 2018), p. 2.

${ }^{2}$ UNHCR, "Contribution to the Fifteenth Coordination Meeting on International Migration," February 10, 2017, UN/POP/MIG-15CM/2017/14.

${ }^{3}$ See, for example, the World Refugee Council supported by the government of Canada (www.worldrefugeecouncil.org); Alexander Betts and Paul Collier, Refuge: Rethinking Refugee Policy in a Changing World (New York: Oxford University Press, 2017); Robin Cohen and Nicholas Van Hear, "Visions of Refugia: Territorial and Transnational Solutions to Mass Displacement," Planning Theory and Practice 18, no. 3 (2017), pp. 494-504; and initiatives promoted by leading experts such as James Hathaway and Alexander Aleinikoff.

${ }^{4}$ On this dynamic see, for example, Hannah Arendt, The Origins of Totalitarianism (New York: Harcourt, 2001); Emma Haddad, The Refugee in International Society: Between Sovereigns (Cambridge: Cambridge University Press, 2008); and Megan Bradley, "Rethinking Refugeehood: Statelessness, Repatriation, and Refugee Agency," Review of International Studies 40, no. 1 (2014), pp. 101-23.

${ }^{5}$ See, for instance, Matthew Gibney, The Ethics and Politics of Asylum (Cambridge: Cambridge University Press, 2004); Phil Orchard, A Right to Flee (Cambridge: Cambridge University Press, 2014); and Alexander Betts, Protection by Persuasion (Ithaca: Cornell University Press, 2009).

${ }^{6}$ Article $1(A)(2)$. Geographic and temporal limitations on the refugee definition in the convention are lifted in the protocol.

7 Regional standards such as the 1969 Organization for African Unity Convention Governing the Specific Aspects of Refugee Problems in Africa offer broader legal definitions, but these agreements are limited in scope. I use the term "refugee" broadly here, including all those who have been forced from their homes. 
${ }^{8}$ Jennifer Hyndman and Alison Mountz, "Another Brick in the Wall? Neo-Refoulement and the Externalization of Asylum by Australia and Europe," Government and Opposition 43, no. 2 (2008), p. 250.

9 See, for instance, Joseph Carens, The Ethics of Immigration (New York: Oxford University Press, 2013); and Seyla Benhabib, The Rights of Others: Aliens, Residents, and Citizens (Cambridge: Cambridge University Press, 2004).

${ }^{10}$ For example, see Natasha King, No Borders: The Politics of Immigration Control and Resistance (London: Zed Books, 2016).

${ }^{11}$ David Miller, Strangers in Our Midst: The Political Philosophy of Immigration (Cambridge, Mass.: Harvard University Press, 2016); and Michael Walzer, Spheres of Justice (New York: Basic Books, 1983). To clarify, I do not personally concur with these theorists' perspectives.

12 Nigel Biggar, "A Christian View of Humanitarian Intervention," Ethics \& International Affairs 33, no. 1 (2019), pp. 19-28.

13 Owing to space considerations, in this discussion I do not address in detail the question of refugees' states of origin. On this issue, see, for example, Megan Bradley, Refugee Repatriation: Justice, Responsibility and Redress (New York: Cambridge University Press, 2013).

${ }^{14}$ Gareth Evans, "Introduction," Ethics \& International Affairs 33, no. 1 (2019), p. 15.

15 Cohen and Van Hear, "Visions of Refugia."

${ }^{16}$ Many of the backers of the myriad reform programs floated in recent years are well aware of the depth and complexity of the refugee predicament and the impossibility of definitively resolving tensions between laws, values, and interests surrounding forced migration, to say nothing of tensions and outright conflicts between the diverse moral claims advanced by refugees, states, and different citizenries. Yet such complexities are rarely acknowledged by experts as they strive to make pithy, policy-relevant recommendations.

17 David Turton, "Forced Migration and the Nation State," in Jenny Robinson, ed., Development and Displacement (New York: Oxford University Press, 2002), pp. 19-76.

18 Arendt, Origins, p. 267.

19 See, for instance, Bradley, "Rethinking Refugeehood"; and Megan Bradley, James Milner, and Blair Peruniak, eds., Refugees' Roles in Resolving Displacement and Building Peace: Beyond Beneficiaries (Washington, D.C.: Georgetown University Press, 2019).

${ }^{20}$ Haddad, Between Sovereigns.

${ }^{21}$ This section draws on Megan Bradley, "Resolving Refugee Situations: Seeking Solutions Worthy of the Name," World Refugee Council Research Paper (Waterloo: CIGI, 2018).

${ }^{22}$ UNHCR Statute, ch. 1, para. 1.

23 UNHCR, “Global Trends 2016" (Geneva: UNHCR, 2017), pp. 3, 24.

${ }^{24}$ See, for example, Andrew Shacknove, "Who Is a Refugee?" Ethics 95, no. 2 (1985); Bradley, Refugee Repatriation; and Lucy Hovil, "Local Integration," in Elena Fiddian-Qasmiyeh et al., eds., The Oxford Handbook of Refugee and Forced Migration Studies (New York: Oxford University Press, 2014).

${ }^{25}$ Return may be legally required after the formal revocation of refugee status, following provisions in the 1951 Convention. These provisions are, in practice, rarely applied.

${ }^{26}$ Linda Bosniak, The Citizen and the Alien: Dilemmas of Contemporary Membership (Princeton: Princeton University Press, 2006), p. 1. From some moral perspectives, enabling refugees to exercise their right of return is all the more important in cases such as the ethnic cleansing of the Rohingya from Myanmar, as this checks the state's power to unilaterally expunge an unwanted group. In such cases, paradoxically, repatriation may be the most preferable option on some moral grounds, precisely when it is riskiest for individual refugees who will unquestionably face hostility upon their return-raising a host of other moral concerns.

27 On the desire of Palestinian refugees to return, and their diverse and complex interpretations of what "return" means, see Diana Allan, Refugees of the Revolution: Experiences of Palestinian Exile (Stanford: Stanford University Press, 2014), pp. 191-212.

Abstract: Worldwide, growing numbers of refugees are pushed from their homes. At the same time, fewer and fewer are able to access so-called "durable solutions" to their displacement. This has prompted a flurry of efforts to repair the foundering refugee regime. Many such efforts attempt, implicitly or explicitly, to resolve tensions between legal principles, moral duties, and national interests surrounding refugees. As part of a roundtable on "Balancing Legal Norms, Moral Values, and National Interests," this essay questions the drive toward oversimplification that has characterized these debates, recognizing that some such tensions are "baked into" the problem of refugeehood. 
While debates have typically focused on the obligation to admit refugees, and on "responsibility sharing," I advance the conversation by exploring how law, morality, and national interests are entangled in efforts to support durable solutions for refugees, focusing on voluntary repatriation. What does recognition of the intrinsic and in some senses irreconcilable tensions in the refugee regime mean for efforts to support solutions? I argue that advancing durable solutions, however imperfect, for refugees does not mean definitively overcoming these tensions, but rather navigating them to identify context-specific opportunities to reposition refugees as full and equal citizens as a critical step toward reducing their precarity.

Keywords: refugees, refugee regime, durable solutions to displacement, voluntary repatriation, right of return 